\title{
Abnormalities of the lungs and thoracic cage in the Ehlers-Danlos syndrome
}

\author{
JON G AYRES, FM POPE, JF REIDY, TJH CLARK
}

From the Departments of Thoracic Medicine and Radiology, Guy's Hospital, London, and the Medical Research Council Dermatology Research Group, Clinical Research Centre, Northwick Park Hospital, Harrow, Middlesex

ABSTRACT Twenty patients with the Ehlers-Danlos syndrome, (10 type I, six type II, and four type IV) were studied to assess the frequency of respiratory abnormalities in this condition. Five patients $(25 \%)$ had had at least one episode of haemoptysis, but none had any defect of coagulation. There was a high frequency of recurrent sinusitis, notably in those with the type I syndrome. Two patients had bullous lung disease, one of whom (type IV) had had three pneumothoraces and subsequent pleurodesis; he also had tracheomegaly (the Mounier-Kuhn abnormality). Minor skeletal abnormalities such as pectus excavatum were common, particularly in patients with type IV disease. Three patients had the straight back syndrome. There were no consistent spirometric or lung volume abnormalities, but eight patients $(40 \%)$ had a raised gas transfer coefficient (Kco), possibly due to an increased intrapulmonary vascular volume. Two other patients had very low values of Kco that were unexplained.

The Ehlers-Danlos syndrome is an inherited defect of connective tissue characterised by soft and hyperextensible thin skin, hypermobile joints, and a particular tendency to bruising and bleeding. Other associated abnormalities include hernias, varicose veins, large arterial rupture, mitral valve prolapse, various ophthalmic complications, and obstetric problems such as premature rupture of the membranes and perineal tears. ${ }^{1}$ Eight or more clinical types are currently recognised ${ }^{2}$ and specific biochemical abnormalities of collagen are known in Ehlers-Danlos syndrome types II, III, V, VI, and VII (table 1). ${ }^{3}$ There is no evidence to suggest abnormalities of elastin or other connective tissue components, although an abnormality of fibronectin has been described in type VIII. ${ }^{4}$

No systematic study of pulmonary abnormalities in this group of disorders has been reported, although there have been several individual case reports describing pneumothoraces or bullae ${ }^{15-12}$ and haemoptysis ${ }^{8913-18}$.

We have undertaken a study of the clinical features and lung function of a group of patients with Ehlers-Danlos syndrome types I, II, and IV.

Address for reprint requests: Dr Jon Ayres, Department of Chest Medicine, East Birmingham Hospital, Birmingham B9 5ST.

Accepted 10 December 1984

\section{Patients and methods}

Twenty five patients with type I, II, or IV EhlersDanlos syndrome attending outpatients at Northwick Park Hospital, Harrow, were contacted by letter asking if they would be prepared to take part in the study. Eighteen agreed, the remaining two patients in the study having been diagnosed at Guy's Hospital. Age, sex, and Ehlers-Danlos syndrome type are shown in table 2. Eleven were male (aged 11-45 years) and nine female (aged 15-45 years). Patients 2 and 3 are the children of patient 1, patient 18 the daughter of patient 17 , and patient 8 the son of patient 7 .

Each patient gave a full medical history, answered a modified Medical Research Council respiratory questionnaire, and underwent clinical examination. Measurements were made of $\mathrm{FEV}_{1}$, forced vital capacity (FVC), and peak expiratory flow rate (PEFR) by standard methods before and after inhalation of bronchodilator. Total lung capacity (TLC) and residual volume (RV) were measured in a body plethysmograph. ${ }^{20}$ Transfer factor for carbon monoxide, both total (TLCO) and corrected for lung volume (Kco), were measured by the single breath method and alveolar volume by helium dilution. Maximal expiratory and inspiratory flow-volume curves were obtained by using an Ohio spirometer 
Table 1 Clinical, genetic, and biochemical classification of the various types of the Ehlers-Danlos syndrome

\begin{tabular}{|c|c|c|c|c|}
\hline Type & & Inheritance & Major manifestations & Biochemical defect \\
\hline I & Gravis & Autosomal dominant & $\begin{array}{l}\text { Marked joint hypermobility and bruising, fragility, hyperextensibility } \\
\text { of skin }\end{array}$ & Unknown \\
\hline II & Mitis & Autosomal dominant & Moderate joint mobility and hyperextensible skin & Unknown \\
\hline III & Benign & Autosomal dominant & Marked joint hypermobility, minimal cutaneous manifestations & Unknown \\
\hline IV & Ecchymotic & Autosomal recessive & $\begin{array}{l}\text { Hypermobility limited to digits, marked skin fragility and bruising, } \\
\text { arterial and gastrointestinal rupture }\end{array}$ & $\begin{array}{l}\text { Deficiency type III } \\
\text { collagen }\end{array}$ \\
\hline V & $\mathrm{X}$ linked & $\mathrm{X}$ linked recessive & $\begin{array}{l}\text { Minimal joint mobility, marked hyperextensibility of skin with } \\
\text { moderate bruising, skeletal disorders }\end{array}$ & $\begin{array}{l}\text { Lysyl oxidase } \\
\text { deficiency }\end{array}$ \\
\hline VI & Ocular & Autosomal recessive & $\begin{array}{l}\text { Appreciable joint hypermobility, very hyperextensible skin with } \\
\text { little bruising, scleral and corneal fragility }\end{array}$ & $\begin{array}{l}\text { Lysyl hydroxylase } \\
\text { deficiency }\end{array}$ \\
\hline VII & $\begin{array}{l}\text { Arthrocalasis } \\
\text { multiplex congenita }\end{array}$ & Autosomal recessive & $\begin{array}{l}\text { Appreciable joint hypermobility, moderate skin fragility with } \\
\text { hyperextensibility and bruising, short stature, } \\
\text { multiple dislocations }\end{array}$ & $\begin{array}{l}\text { Defective conversion of } \\
\text { pro-collagen to } \\
\text { collagen }\end{array}$ \\
\hline VIII & Periodontitic & Autosomal dominant & $\begin{array}{l}\text { Moderate joint mobility and skin fragility but minimal } \\
\text { hyperextensibility, advanced periodontitis }\end{array}$ & Unknown \\
\hline
\end{tabular}

linked to an $\mathrm{X}-\mathrm{Y}$ recorder. Normal ranges were defined as the mean \pm 2 standard deviations from the mean ${ }^{19}$ and values outside these ranges were taken to indicate a significant functional abnormality. Reduced values for $\mathrm{FEV}_{1}$ and $\mathrm{FVC}$ with a normal forced expiratory ratio $\left(\mathrm{FEV}_{\mathrm{l}} / \mathrm{FVC} \%\right.$ (FER)) were regarded as indicating a restrictive ventilatory defect and reduced values of $F E V_{1}$ with a reduced
FER as indicating an obstructive defect. Quasistatic pressure-volume curves of the lungs were obtained for two patients. ${ }^{21}$ Skinprick tests for six common allergens were performed on each patient. A posteroanterior and lateral chest radiograph was obtained in 18 cases. From the lateral radiograph, the distance from the middle of the anterior border of T8 to a vertical line connecting T4 and T12 (the

Table 2 Abnormalities of respiratory history, pulmonary function, and radiology in 20 patients with Ehlers-Danlos syndrome

\begin{tabular}{|c|c|c|c|c|c|c|c|c|}
\hline \multirow[t]{2}{*}{$\begin{array}{l}\text { Patient } \\
\text { No }\end{array}$} & \multirow[t]{2}{*}{ Sex } & \multirow[t]{2}{*}{$\begin{array}{l}\text { Age } \\
(y)\end{array}$} & \multirow[t]{2}{*}{ Smoking } & \multirow[t]{2}{*}{$\begin{array}{l}\text { Skin } \\
\text { Tests }\end{array}$} & \multirow[t]{2}{*}{ Respiratory history } & \multirow{2}{*}{$\begin{array}{l}\text { MRC } \\
\text { grade of } \\
\text { dyspnoea }\end{array}$} & $\underset{k P a / l)}{K C O}(\mathrm{mmol} / \mathrm{min} /$ & \multirow[t]{2}{*}{ Radiological abnormalities } \\
\hline & & & & & & & $\overline{\text { Value Predicted }}$ & \\
\hline
\end{tabular}

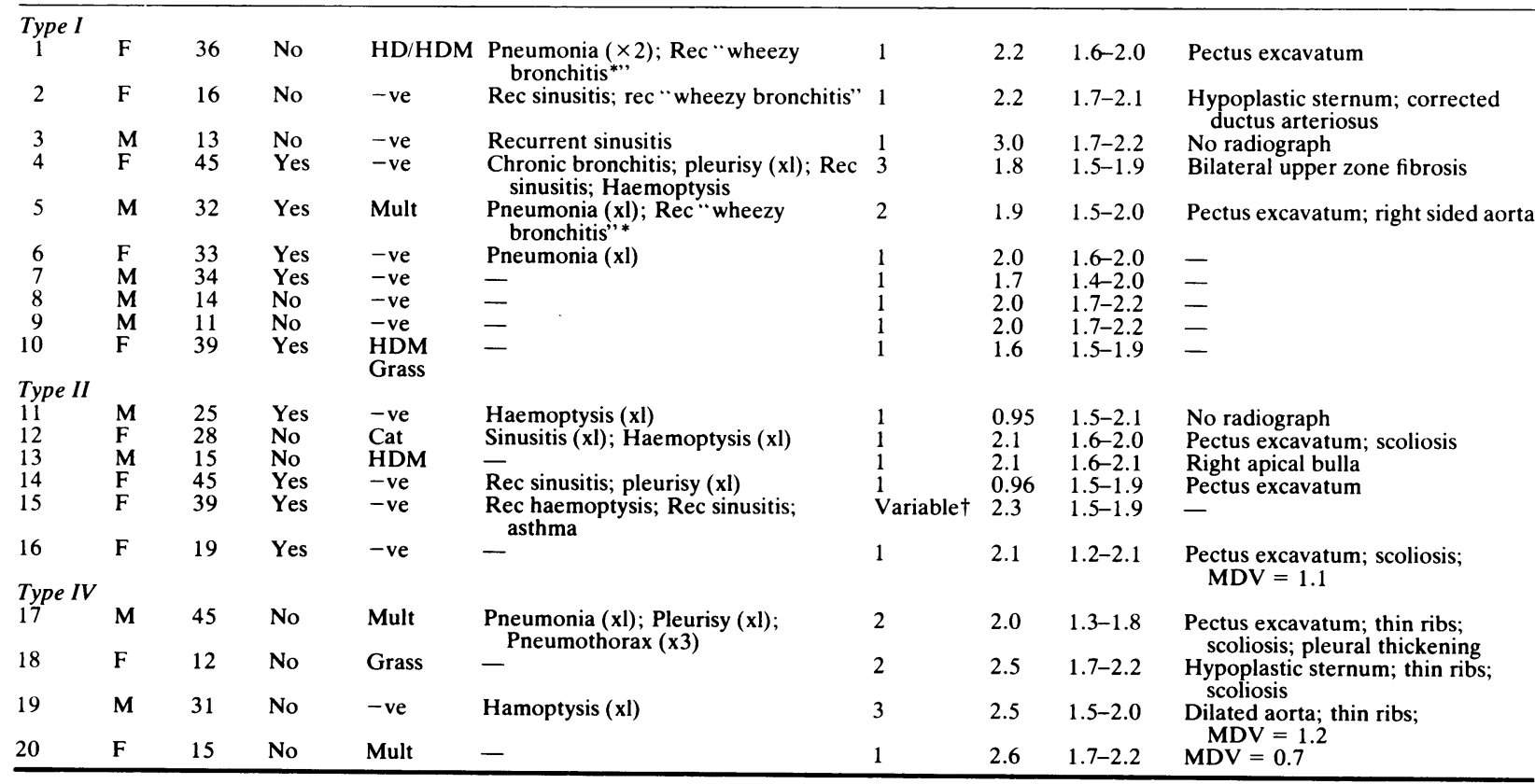

HD—house dust; HDM—-house dust mite, multiple positive skin test responses; KCO—gas transfer coefficient; MDV—mid dorsal value; Rec-recurrent; "wheezy bronchitis": attacks of cough with wheezing. Normal values from Cotes. ${ }^{11}$ The range is calculated from the mean and 1 standard deviation. *Probably asthma.

†Because of asthma. 
Table 3 Measured values of tracheal diameter ( $\mathrm{mm}$ ) at a film focus distance (FFD) of $100 \mathrm{~cm},{ }^{23}$ estimated values for FFD of $150 \mathrm{~cm}$, and suggested upper limit of the normal tracheal diameter for adults at an FFD of $150 \mathrm{~cm}$

\begin{tabular}{lll}
\hline Tracheal diameter & \multicolumn{2}{l}{ Film focus distance } \\
\cline { 2 - 3 } & $100 \mathrm{~cm}$ & $150 \mathrm{~cm}$ \\
\hline Smallest diameter & 13.0 & 12.2 \\
Largest diameter & 25.0 & 23.5 \\
Mean (SD) diameter & 20.2 & 19.0 \\
$\begin{array}{l}\text { Suggested normal upper } \\
\text { limit of tracheal } \\
\begin{array}{l}\text { diameter } \\
\text { (ie mean and 2 SDs) }\end{array}\end{array}$ & 27.4 & $(3.2)$ \\
\hline
\end{tabular}

mid dorsal value, MDV) was used as a measure of the straight back syndrome ${ }^{22}$; satisfactory measurements were obtained in 15 patients.

The minimum and maximum anteroposterior and lateral diameters of the trachea and, where possible, the right and left main bronchus were measured. In a review of tracheobronchiomegaly (the MounierKuhn abnormality), Katz et $a l^{23}$ established normal ranges for minimum and maximum diameters of the major airways. They, however, used a film focus distance (FFD) of $100 \mathrm{~cm}$ (40 in) for their posteroanterior chest radiographs, compared with $150 \mathrm{~cm}(60$ in) in this study. The respective estimated magnifications would be 1.18 for an FFD of $100 \mathrm{~cm}$ and 1.11 for $150 \mathrm{~cm}$. The normal range of Katz et al and the corrected range for the larger FFD are shown in table 3 .

\section{Results}

\section{RESPIRATORY HISTORY}

The abnormalities of the 20 patients are shown in table 2. Eight $(40 \%)$ of the patients were current smokers. Five patients $(20 \%)$ claimed to be unduly breathless, two of whom (Nos 4 and 19) had a restrictive defect as shown by spirometry. One patient, a heavy smoker, had chronic bronchitis. Three patients (Nos 1, 15, and 17) gave a history of attacks of wheezing and patient 15 was shown subsequently to have asthma. Five patients (25\%) reported at least one episode of haemoptysis, usually associated with a respiratory tract infection, although two patients coughed up blood over prolonged periods of time. One of these latter patients had polycythaemia rubra vera.

Five patients, all with type I Ehlers-Danlos syndrome, gave a history of recurrent attacks of cough and wheezing. Three were smokers and two nonsmokers. Five patients had recurrent attacks of sinusitis and four had had pneumonia. One patient

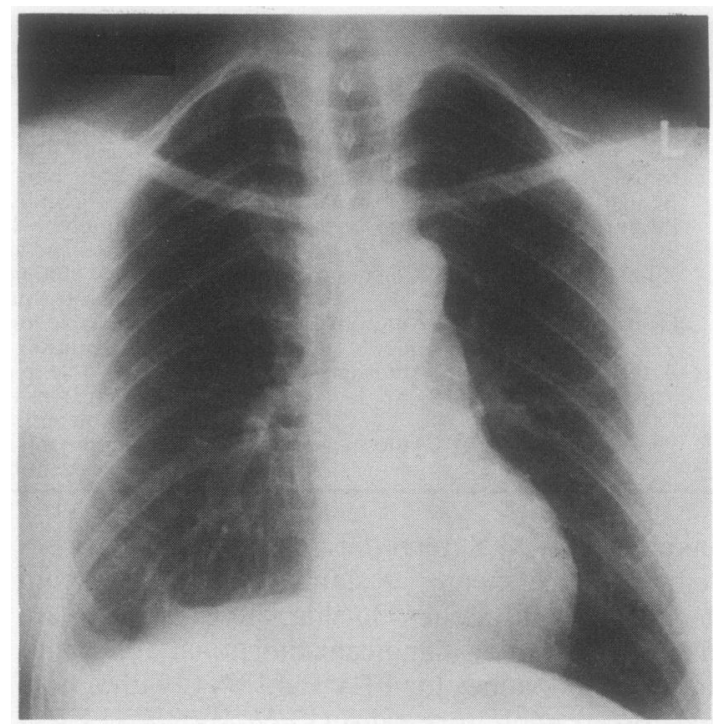

Fig 1 Postanterior Chest radiograph of patient 17 showing thin, tapering ribs and the Mounier-Kuhn abnormality (tracheomegaly), with a minimum tracheal diameter of 27 $\mathrm{mm}$. The pleural changes at the right base are the result of a pleurodesis.

(No 17) had suffered three pneumothoraces and had undergone pleurodesis.

\section{RADIOLOGY}

Eight patients had normal chest radiographs and

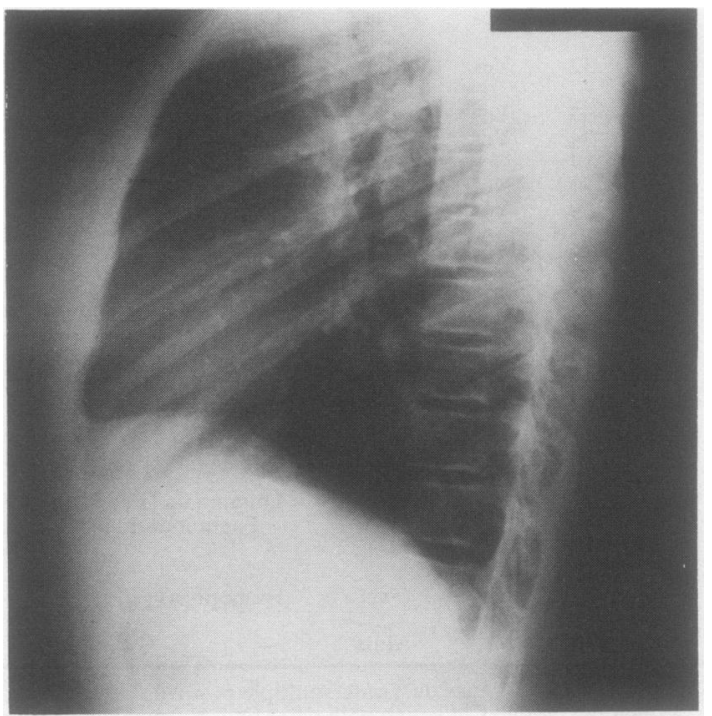

Fig 2 Lateral chest radiograph of patient 20 showing the straight back syndrome (mid dorsal value $0.7 \mathrm{~cm}$ ). 


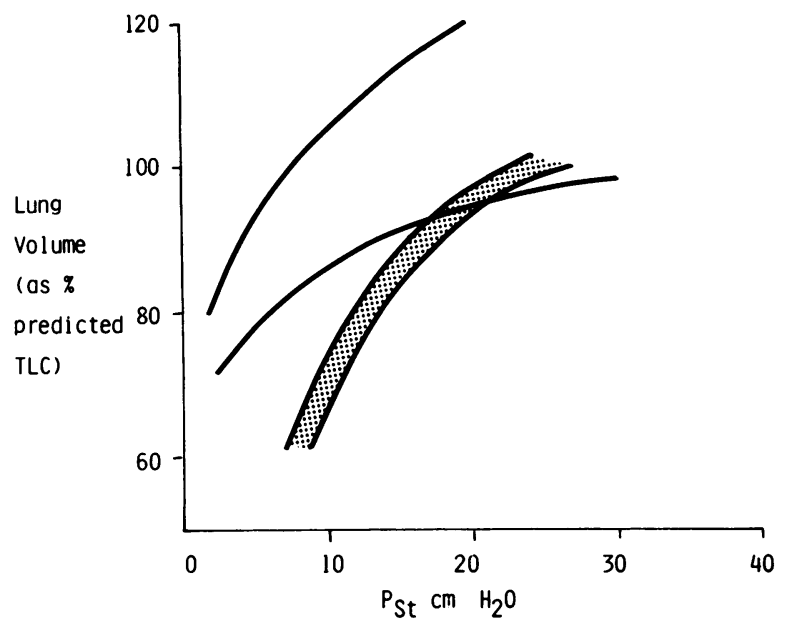

Fig 3 Pressure volume curves of the lungs in 2 patients (Patient no 12-upper curve; patient no 6-lower curve). The curves shown are best fit curves for values of lung recoil pressure $\left(P_{s t}\right)$ at volume intervals of $10 \%$ predicted TLC, averaged from several quasistatic deflation manoeuvres. Shaded area represents normal range for young women. ${ }^{21}$

two patients did not have radiographs taken. The others showed various abnormalities.

Skeletal abnormalities Six patients had mild pectus excavatum and three had very thin ribs with a characteristically increased downward slope (fig 1). A mild scoliosis was seen in four patients. Three with mid dorsal values of $1.1,1.2$, and $0.7 \mathrm{~cm}$ fitted the criteria for the straight back syndrome (fig 2). The mean MDV for the 15 patients in whom accurate measurement was possible was $1.66 \mathrm{~cm}$ (range 0.7-3.1 cm). Two patients, both young girls, had appreciably hypoplastic sternums.

Pulmonary disease One patient had bilateral upper lobe fibrosis and one had a single right apical bulla measuring $5 \times 3.5 \mathrm{~cm}$. Patient no. 17 had bilateral multiple bullae which had resulted in three spontaneous pneumothoraces. He also had tracheomegaly with a maximum tracheal diameter of $27 \mathrm{~mm}$ (fig 1).

Cardiac abnormalities Patient no 5 had a right sided aortic arch and in patient 19 the aorta appeared unfolded for his age. Patient 2, who had had a ductus arterious ligated, had a normal cardiac contour.

\section{RESPIRATORY FUNCTION TESTS}

The results are summarised below and in table 2; a full table of pulmonary function measurements is available on request.

Spirometry and flow volume curves One patient (No 3) showed a restrictive defect on spirometry and two (nos 15 and 19) had a mixed obstructive and restrictive defect. Patient 15 , who smoked and had asthma, showed an increase in $\mathrm{FEV}_{1}$ of more than $15 \%$ on inhaling $2.5 \mathrm{mg}$ of nebulised salbutamol. Patient 19 had never smoked and showed no improvement in $\mathrm{FEV}_{1}$ with $2.5 \mathrm{mg}$ nebulised salbutamol. Seven patients showed a slight "scoop" on the expiratory limb of the flow-volume curves, suggesting mild airflow obstruction.

Lung volumes TLC was reduced in six patients (nos 3, 4, 13, 15, 17, and 19). One of these (no 4) had radiographic evidence of bilateral apical fibrosis and one (no 17) had had a pleurodesis for recurrent pneumothoraces.

Gas transfer Eight patients $(40 \%)$ had a KCO value of more than $1 \mathrm{SD}$ above the mean predicted value (Nos 1, 2, 3, 12, 15, 17, 19, 20). Four of these (Nos $3,15,17$, and 19) had a reduced alveolar volume and TLC. One further patient (No 18) had a high KCO; both the TLCO and TLC were normal, but VA was unexpectedly low and the apparently high $\mathrm{KCO}$ is assumed to result from a technical error. Two patients (Nos 11 and 14) had reduced values of KCO and TLCO with normal lung volumes.

Pressure-volume curves Pressure-volume curves were obtained in two patients (Nos 6 and 12) and are shown in figure 3. The curve for patient 12 is shifted upwards and to the left, but her spirometric values were normal, and this apparent shift is likely to be simply a reflection of her above average TLC, which was nevertheless within the normal range. Skin tests Eight patients had one or more positive skinprick test reactions.

\section{Discussion}

A range of abnormalities was observed in our patients, but there was no particular correlation with the clinical classifications of the disease.

Seven cases of pneumothorax in Ehlers-Danlos syndrome have been reported 1578111224 and three of these patients certainly had type IV disease. ${ }^{58}$ The patient described by Clark $e t a l^{7}$ had bullae and type III collagen deficiency. Bullae were also reported in three other cases. ${ }^{1911}$ The patient reported by Baumer and Hankey ${ }^{6}$ probably had a pneumatocoele, the diagnosis of Ehlers-Danlos syndrome being coincidental. Pneumothorax appears to be less commonly seen in Ehlers-Danlos syndrome than in Marfan's syndrome. ${ }^{25}$

Twenty five per cent of our patients had had at least one haemoptysis. This has previously been described in Ehlers-Danlos syndrome, ${ }^{891318}$ and in one patient ${ }^{18}$ it may have been due to bronchiectasis. The interesting patient of Grant and Adler' ${ }^{16}$ had diffuse intrapulmonary haemorrhage of obscure cause. Although minor abnormalities of clotting 
have been documented in Ehlers-Danlos syndrome $^{26}$ there was no correlation between such abnormalities and a history of haemoptysis in our patients.

A history of recurrent sinusitis and pneumonia was relatively common in our patients, notably in patients with type I disease.

Tracheobronchiomegaly was first described by Mounier-Kuhn and Meyer in $1949,{ }^{27}$ and the clinical and radiological features have since been well described by Katz et $a^{23}$ and Himalstein and Gallagher. ${ }^{28}$ There has been one previous report ${ }^{29}$ of a patient with Ehlers-Danlos syndrome and the Mounier-Kuhn abnormality, and Wanderer et $a^{30}$ described the association of tracheomegaly with acquired cutis laxa. One further patient, with emphysema and untyped Ehlers-Danlos syndrome, was reported as having tracheobronchiomegaly; but no measurements were given. ${ }^{31}$

The major abnormality of lung function was a raised gas transfer coefficient in eight patients. This finding may be due to increased pulmonary blood volume or intrapulmonary haemorrhage but various other causes are known. ${ }^{32}$ One possibility is that the various collagen defects responsible for the different types of Ehlers-Danlos syndrome may alter the permeability or distensibility of blood vessel walls. Subtle abnormalities of type I, III, or basement membrane collagen could be implicated here. The total carbon monoxide transfer factor in these patients was not, however, increased. An alternative explanation is that the raised $\mathrm{KCO}$ in some patients resulted from extrapulmonary volume restriction due to thoracic cage abnormalities, although the abnormalities that we detected were relatively minor. There is no obvious explanation for the low Kco observed in patients 11 and 14. Pressurevolume curves were not obtained in these two patients, but emphysema is unlikely as flow-volume curves and lung volumes were normal.

The pressure-volume curves obtained in patients 6 and 12 are inconclusive but they show no evidence of generalised emphysema and the available histological evidence ${ }^{7}$ suggests that when bullae are present they are not usually associated with generalised emphysema. One patient (possibly having a new subtype of Ehlers-Danlos syndrome) has, however, been reported with severe panacinar emphysema ${ }^{33}$ but this appears to be rare in EhlersDanlos syndrome, in contrast with the severe, early onset emphysema seen in cutis laxa, a condition characterised by abnormal elastic fibres. ${ }^{34}$

Finally, various minor skeletal abnormalities were detected. These included thin, sloping ribs in three of the four patients with type IV disease, as has previously been described..$^{35}$ Our patients had only minor degrees of scoliosis, as is usual in these particular types of Ehlers-Danlos syndrome. Severely deforming scoliosis is well known to be associated with lysyl hydroxylase deficiency (type VI EhlersDanlos syndrome), ${ }^{136}$ although it has been described in other types. ${ }^{37}$ By radiological criteria $20 \%$ of our patients had the straight back syndrome. 2238

Our findings suggest a variety of thoracic abnormalities in Ehlers-Danlos syndrome. Bullae and pneumothoraces are not uncommon, especially in type IV disease, in which type III collagen deficiency also leads to thin skin and arterial rupture. ${ }^{39}$ No consistent abnormality of lung function was detected but nearly half of our patients had an increased gas transfer coefficient. Ehlers-Danlos syndrome should be considered as a diagnosis in the presence of premature bullous disease, recurrent pneumothorax, or unexplained haemoptysis.

We are very grateful for the advice of Dr MK Davies, the secretarial assistance of Mrs P Jackson, and the technical help of Martin King and the staff of the respiratory function unit at Guy's Hospital.

\section{References}

1 McKusick VA. Heritable disorders of connective tissue. 4th ed. (1972). St Louis: CV Mosby and Sons, 1972.

2 Bauer EA, Uitto J. Collagen in cutaneous diseases. Int J Dermatol 1979;18:251-70.

3 Pope FM, Martin GR, Lichtenstein JR. Patients with Ehlers-Danlos syndrome type IV lack type III procollagen. Proc Natl Acad Sci USA 1975;72:1314-6.

4 Arneson MA, Hammerschmidt DE, Furcht LT, King RA. A new form of Ehlers Danlos syndrome. Fibronectin corrects defective platelet function. JAMA 1980;244: 144-8.

5 Andre R, Duhamel G, Bergoz D, Lavallee R. Incidences hemorragiques et viscerales de la maladie d'Ehlers Danlos. Bull Soc Med Hôp Paris 1965;1161:971-6.

6 Baumer JH, Hankey S. Transient pulmonary cysts in an infant with the Ehlers-Danlos Syndrome. $B r J$ Radiol 1980;53:598-9.

7 Clark JG, Kuhn C, Uitto J. Lung collagen in type IV Ehlers-Danlos syndrome. Ultrastructural and biochemical studies. Am Rev Respir Dis 1980;122: 971-8.

8 Graf CJ. Spontaneous carotid cavernous fistula. Ehlers-Danlos syndrome and related conditions. Arch Neurol 1965;13:662-72.

9 Mire B, LeDoux A, Hoeffel JC. Dystrophie pulmonaire bulleuse au cours d'une maladie d'EhlersDanlos. A propos d'une observation. Ann Radiol 1976; 19:721-4.

10 Packer BD, Blades JF. Dermatorrhexis: a case report (the so-called Ehlers-Danlos syndrome). Virginia Medical Monthly 1954;81:21-30.

11 Smit J, Alberts C, Balk AG. Pneumothorax in the 
Ehlers-Danlos syndrome. Consequences or coincidence? Scand J Respir Dis 1978;59:239-42.

12 O'Neill S, Sweeney J, Walker F, O'Dwyer WF. Pneumothorax in the Ehlers Danlos syndrome. Irish $J$ Med Sci 1981;150:43-4.

13 Ayres J, Rees J, Cochrane GM. Haemoptysis and non-organic upper airways obstruction in a patient with previously undiagnosed Ehlers-Danlos syndrome. Br J Dis Chest 1981;75:309-10.

14 Beighton P. Lethal complications of the Ehlers-Danlos syndrome. Br Med J 1968;iii:656-9.

15 Cordier JF, Ardisson P, Touraine R. Le syndrome d'Ehlers-Danlos. Une cause rare d'hemoptysie. Nouv Presse Med 1981;10:1847.

16 Grant AK, Adler TAM. Haemorrhage into the upper part of the gastro-intestinal tract in three patients with heritable disorders of connective tissue. Aust Ann Med 1967; 16:75-9.

17 Jacobs PH. Ehlers-Danlos syndrome. Report of a case with onset at age 29. Arch Dermatol 1957;76:460-2.

18 Robitaille GA. Ehlers-Danlos syndrome and recurrent haemoptysis. Ann Intern Med 1964;61:716-21.

19 Cotes JE. Lung function: assessment and application in medicine. 4th ed. Oxford: Blackwell Scientific publications, 1979.

20 Dubois AB, Botelho SY, Comroe JH. A new method for measuring airways resistance in man using a body plethysmograph: values in normal subjects and in patients with respiratory disease. J Clin Invest 1956;35:327-35.

21 Gibson GJ, Pride NB. Lung distensibility. The static pressure-volume curve of the lungs and its use in clinical assessment. Br J Dis Chest 1977;70:143-84.

22 Davies MK, Mackintosh P, Cayton RM, Page AJF, Shiu MF, Littler WA. The straight back syndrome. $Q J$ Med 1980;196:443-60.

23 Katz I, Levine M, Herman P. Tracheobronchiomegaly. The Mounier-Kuhn syndrome. Am J Roentgenol 1962;88: 1084-94.

24 Ferte JF. Le syndrome d'Ehlers-Danlos. A propos d'un cas complique de pneumothorax spontaniée et de varices des membres inferieurs. Thèse Med, Reims, 1972 No 45. (Quoted by Mire et al..$^{9}$ )

25 Wood JR, Bellamy D, Child AH, Citron KM. Pulmonary disease in patients with Marfans syndrome. Thorax
1984;39:780-4.

26 Winter M, Needham J, Pope FM, Barkhan P. Defective platelet aggregation in the Ehlers Danlos syndrome. Thromb Haemostas 1983;50:213.

27 Mounier-Kuhn P, Meyer L. Mega-organes: oesophage, trachee, colon; syndromes de Mikulicz et d'EhlersDanlos, chez une heredo-syphilitique. Lyon Med 1949;171: $169-75$.

28 Himalstein MR, Gallagher JC. Tracheobronchiomegaly. Ann Otol 1973;82:223-7.

29 Aaby GV, Blake HA. Tracheobronchiomegaly. Ann Thorac Surg 1966;2:64-70.

30 Wanderer AA, Ellis EF, Goltz RW, Cotton EK. Tracheobronchiomegaly and acquired cutis laxa in a child. Physiologic and immunologic studies. Pediatrics 1969;44:709-15.

31 Cavanaugh MJ, Cooper DM. Chronic Pulmonary Disease in a child with the Ehlers-Danlos Syndrome. Acta Paediatr Scand 1976;65:679-84.

32 Lipscomb DJ, Patel K, Hughes JMB. Interpretation of increases in the transfer coefficient for carbon monoxide. Thorax 1978;33:728-33.

33 Cupo LN, Pyeritz RE, Olson JL, McPhee SJ, Hutchins GM, McKusick VA. Ehlers Danlos syndrome with abnormal collagen fibrils, sinus of Valsalva aneurysms, myocardial infarction, panacinar emphysema and cerebral heterotopias. Am J Med 1981;71:1051-8.

34 Turner-Stokes L, Turton C, Pope FM, Green M. Emphysema and cutis laxa. Thorax 1983;33:790-2.

35 Coventry MB. Some skeletal changes in the Ehlers Danlos syndrome. A report of two cases. J Bone Joint Surg 1961;43A:855-60.

36 Krane SM, Pinnel SR, Erbe RW. Lysyl protocollagen hydroxylase deficiency etc. Proc Natl Acad Sci 1973;69:2899-903.

37 MacFarlane IL. Ehlers-Danlos syndrome presenting certain unusual features. J Bone Joint Surg 1959;41B: 541-5.

38 Rawlings MS. The "straight back" syndrome, a new cause of pseudoheart disease. Am J Cardiol 1960; 5:333-8.

39 Rudd NL, Nimrod C, Holbrook KA, Byers PH. Pregnancy complications in type IV Ehlers-Danlos syndrome. Lancet 1983; i:50-3. 